\title{
THE HARTER ACT AND BILLS OF LADING LEGISLATION.*
}

I.

At the last Conference of the International Law Association, held at Christiania in September, Ig05, Professor Oscar Platou presented an interesting paper on the legal relations between chartere-s and shipowners. He proposed as a matter for discussion a resolution passed by the Commercial Congress in Copenhagen in 1903 , which was to the following effect:

"That efforts should be made to pass a law, which should enact:

"That all contract clauses in bills of lading, charter-parties and similar agreements respecting maritime conveyance, purporting to limit or nullify the ordinary rules of law respecting the liability of shipowners for due care in providing for the seaworthiness, the ourfit, manning and provisioning of the vessel, and likewise in the reception, stowing, dunnaging, separation and delivery of the goods, shall be invalid, whether the contracts be made here or abroad, and even when reference is made in such documents to foreign laws or customs."

He added that there would be no objection to make stipulations in such a law, as has been done in the Harter Act, once for all relieving the owners of liability in respect of the so-called nautical errors-that is, errors on the part of the masters and crews with respect to navigation; but so that it be sharply and precisely defined that the owner's liability for proper treatment of the goods will in no way be affected thereby.

In the course of the ensuing debate, Mr. Douglas Owen expressed himself to the effect that he personally should rejoice to see legislation on lines similar to the Harter Act introduced into British legislation. But, he said, it was scarcely probable that the British legislature could be induced to interfere until there happened certain strong cases appealing strongly to the public sense of right and justice, which might call for legislation in the sense indicated by Mr. Platou. Until then, he thinks, we shall have to make

* This paper was read by Dr. Sieveking at the Berlin Conference of the International Law Association, Oct. 5, 1906. [ED.] 
up our minds to go on as we are going. And what he would like to see was an alternative bill of lading-the one bill of lading much on the present lines, in which the shipowner is liable for nothing except to receive his freight in advance; the other, in which, in consideration of a higher freight, the shipowner accepts liability for damages arising out of ill-treatment of the cargo. A resolution was then submitted to the conference, to the effect:

"That there is a demand for compulsory clauses in charterparties in the same direction as those indicated in the United States Harter Act with regard to the legal relations between charterer and shipowner."

Twelve votes were given in favor of this resolution and twelve against it, whereupon the resolution was lost by the casting vote of the chairman.

This result of the debate shows that the important questions which formed the subject of the discussion have as yet not met with a decisive solution, and this circumstance alone would suffice to justify another word on the subject. Another reason for my taking up the discussion is that it seems expedient to bring to the knowledge of this association two facts, which, it is true, have been alluded to already at the Christiania meeting, but which deserve a somewhat more extensive explanation.

\section{II.}

The first of these facts is the result of an International Conference of Underwriters, held in Paris in 1900 . This conference was attended by a great number of representatives of marine insurance companies from Paris, Havre, Hamburg, London, Berlin, Mannheim, Milan, Liverpool, Copenhagen, Antwerp, St. Petersburg, Gothenburg, Stockholm, Amsterdam, Rotterdam, Turin, Bale, Zürich. In his address to the conference the president pointed out that, in consequence of the underwriters having accepted their liability for damages to or loss of goods shipped under bills of lading which contain the negligence clause and the other usual exonerating clauses, the insurance on goods, whose original purpose was to cover accidents of the sea only and accidents of navigation arising out of faults of master and crew, had come to protect the shipowner against "commercial faults" committed by his agents and employees in the fulfilment of contracts entered into by the shipowner. This extension of liabilities, so the president argued, ought to be abolished because it led to this, that the fulfilment of contracts which were destined to secure a safe transportation of goods was neglected, and the 
responsibility for the carrying out of such contracts was taken off the shoulders of those to whom in law and equity it should attach.

The result of this conference was that a resolution was unanimously adopted to the following effect:

"The conference resolves that in policies on goods the following clause be inserted:

"The insurers on goods do not take at their charge the consequences of clauses inserted in bills of lading or charter-parties which relieve the shipowner from his liabilty for commercial faults of master and crew, such as are referred to in the United States law called the Harter Act of I3th February, I893.

"The insurers accept the clause exonerating the shipowner from nautical faults committed in the navigation of the vessel."

Moreover, it has been unanimously resolved to establish committees at the different local centers of marine insurance business, with a view to communicate with each other, and jointly to examine all questions of common interest, as well as to realize the execution of the adopted resolution.

The carrying out of the aforesaid resolution has been postponed for a short time, in order to await the result of a movement which shortly afterwards was brought about with the view of inducing legislatures to interfere.

This movement is the other fact of importance in the consideration of the questions with which I am dealing.

III.

In a Conference of French Shippers held at Marseilles in October, I902, certain resolutions were adopted, which, later on, were adhered to by a large number of French Chambers of Commerce and other bodies representing various merchants and mercantile societies of France. These resolutions recommended the adoption of a law allowing shipowners to decline their liability for nautical faults of master and crew, and prohibiting them from declining such liability for commercial faults of the shipowners' employees in the carrying out of affreightment contracts.

A mixed committee, consisting of French shippers and shipowners, met at Paris in May, 1903, to consider the question. In this committee the shipowners brought forward a proposal which had already been made by the Delegates of the Syndicates of French Shipowners as far back as 1896 , viz.: an alternative bill of lading, the one containing the full legal liability of the shipowner; the other containing the exonerating clauses. The former to be handed to the shipper, as a rule, in case of no special agreement as to the 
freight having been made; the latter to be framed according to the special stipulations agreed upon.

This system of a double bill of lading has been actually put into practice by some French shipowners. But it appears that Frenci shippers seldom choose the bill of lading containing the full liability, but generally prefer the bill of lading charged with the exonerating clauses. This seems to be the natural consequence of the fact that as long as the shippers are protected by insurance there is no reason for them to refuse the bill of lading with exonerating clauses.

The shippers, not being satisfied with the offer made by the shipowners, continued their efforts to bring about an intervention of legislation, and in February, 1904, an interministerial committee was appointed by the French government, and ordered to examine whether it was advisable to modify the existing French law with regard to bills of lading. The committee met under the presidency of Mr. Durand, member of the French Cour de Cassation, and contained ten other distinguished lawyers, government officials and merchants. The committee has heard the views of Delegates of French Shippers, Delegates of the Central Committee of French Shipowners and Delegates of French Underwriters.

The shippers accepted the clauses exonerating the owner from liability for neglects and defaults of master and crew in navigating the vessel and the underwriters declared their willingness to submit to such clauses. So far as these clauses were concerned there appeared to be no reason for a change of the existing law, which allows the inserting of such clauses in charter-parties or bills of lading.

Difference of opinion, however, arose as to the liability for socalled commercial faults of master and crew and other employees of shipowners. The shippers objected to the clauses exonerating the shipowners from liability for loss or damage of goods caused by negligent storage, by theft, or by the neglect of proper care in the fulfilment of such duties as in all contracts must be performed by paid employees. They argued that by these clauses negligence was encouraged, that in fact they amounted to a premium on negligence, and even on fraud. They declared that it was contrary to law and equity, that shipowners should be allowed to leave the goods on quays or in lighters, before shipment or after discliarging, at the risk of the shippers or consignees, for a certain time, say for the interval between the departure of one vessel and that of the next following of the same line; and further objected that shipowners, by clauses in the bills of lading, were allowed to keep goods on board for several 
successive voyages, or to discharge them at a port beyond the port of destination, and to return them at the risk of the shippers or consignees, instead of properly delivering them at the port of destination; that clauses in the bills of lading allowed the shipowners to tranship the goods into other vessels, even foreign, and not belonging to their own line, and of an inferior class, and without notice to the parties interested-to load goods on deck without notice given to the shipper-to bring into general average damages suffered by engines and expenses of lighterage caused by the vessel coming aground without an imminent peril-to limit their liability arising out of belated delivery to cases of a delay exceeding three or four months, and to a certain low amount-and generally to decline all and every liability for faults and neglects of their employees, master and crew or others.

The shippers also represented to the committee that they were unable to make agreements to a contrary effect, owing to the power of the shipowners and their faculty of combining amongst themselves; that part of the enumerated risks, $e . g$., the risk of delay in delivery, could even now not be covered by insurance, and that if the resolutions taken at the Underwriters' Conference at Paris in Igoo were put into effect they would be unable to protect themselves by insurance against all those risks. Further, that, apart from this, it was no argument against their reasoning to say that they could protect themselves by insurance against wrongs illegally suffered by them, and that it would be unjust to say that without an international agreement the question could not be settled in the way proposed by them because the experience of the Harter Act showed that national legislation could interfere without any prejudice to the interests of the national shipowners. On the contrary, the continuance of the present state of affairs would seriously prejudice the interests of the national shipowners because the shippers would be led to prefer the flags of such countries where clauses of the nature described were not in use.

The underwriters on cargo, in a memorandum presented to the committee, declared that, although they took a lively interest in the debate because whatever served to diminish their risk would only be welcome to them, still their position was simply this, that if the movement proved abortive, they would put into practice the resolutions adopted at the Paris Conference in 1900, and thus free themselves from liabilities which, according to law and to the nature of marine insurance, ought to rest on the shipowners and not on the underwriters on cargo. 
The shipowners gave the following reasons for opposing the demands of the shippers. They said that they had offered the alternative bill of lading-the one covering the so-called commercial faults of a somewhat higher freight-and that this was all the shippers could in equity desire. If the shippers refused to accept this offer, they would have to insure the risk of the clauses, and they certainly would be able to do it because the underwriters, owing to the competition of foreign, especially British, insurers would never be able to carry out their threats to discontinue the insurance of those risks. If, on the other side, the proposed reform by legislation were adopted, the French shipowners would be prejudiced in favor of the underwriters, the greater part of whom, moreover, were foreign underwriters, and of foreign shipowners. Finally the shippers themselves would be the sufferers because by impeding the development of export and import of goods from and into French ports they would deprive themselves of facilities for procuring the goods required for their industry and for creating markets for the sale of the produce of their industry in foreign countries.

IV.

The committee, after a careful examination, arrived at the following conclusion:

"That it is not advisable to alter the actual law on bills of lading, for the reasons: that public order does not in this respect require an interference with the principle of liberty of contracts; that, in the present condition of the relations of maritime commerce, it is always possible to meet the inconveniences arising out of the irresponsibility of shipowners, either by the alternative bill of lading, or by insurance in its various forms; finally, and above all, that the proposed reforms would lead to serious difficulties with regard to international law, and that, from a commercial point of view, they would place the French shipowners in an evidently inferior position as regards foreign shipowners, so that without the concurrence of all other nations the proposed reform evidently cannot be realized."

The reasons by which the committee has been guided are laid down in a report drawn up by Mr. Rousseau, Avocat à la Cour d'Appel de Paris, dated Paris, March 19th, rgo6. The following is an abstract of his report:

First of all there is no reason for an alteration of the law regarding sailing-vessels because the complaints are made against the steamship owners only, nor of the law regarding charter-parties because the complainants themselves acknowledge that as far as regards the negotiation of an affreightment by charter-party no. 
protection of the merchant against the principle of liberty of contracts is required. It is on bills of lading only that the dispute turns because the merchants say that there is no possibility for them to contest the bill of lading clauses, and that practically the shipowners in this respect enjoy a monopoly.

It has then been considered that at present-with the sole exception of the United States and of Australia-the clauses of irresponsibility are universally in use. This seems to prove that commercial necessities have led to such a situation. It is a fact that in the course of the last twenty or thirty years freights have gone down very considerably, so much so that on some routes the freight is but five per cent of what it was formerly. Besides this deterioration of the position of a shipowner, the modern changes in navigation and naval industry have brought about new risks. It is against these risks that the shipowners want to protect themselves by the clauses of irresponsibility. The proposed reform would enhance the risks of the shipowner and lead to the necessity of their covering these enhanced risks by insurance, and, in order to cover the costs of insurance, to raise the freight rates. If they did not do so, they would evidently be at a disadvantage compared with foreign shipowners. If they did so, French shippers would avail themselves of foreign ships for transport of their goods, and thus contribute to ruin the French commercial navy, or, if they did not do this, the increase in the costs of exporting and importing goods would damage the producing industry of the nation. Therefore it clearly appears that the reforms, if necessary, could be brought about by international legislation only, agreed upon by all, or at least the six or seven leading maritime nations.

The report then goes on to examine the difference between navigation now and in former times. Formerly, the value of ships, as well as cargoes, was vastly inferior to what it is now. Consequently the risks incurred by the shipowners were less. Besides, vessels now are of so complicated a structure and require such numerous and often changing crews that the risk of accidents is increased and the possibility of controlling the crews considerably impaired. Cargoes must be stowed and discharged with an ever-increasing haste. In intermediate ports the necessary shortness of the stay prevents a careful control in the taking in and discharging of cargoes. The work goes on day and night. Bad weather in open roadsteads augments the difficulties. Occasions are more numerous for theft and damaging of goods. Shipmasters must be chosen amongst those who have passed the examinations required by law; therefore, it 
would be a hardship to make the owner liable for the master's management of commercial affairs to which he has not been educated. As to the crew, they are not able to judge of what is required for a safe navigation and for a proper stowage. As to short delivery of goods, it must be taken into consideration that frequently shippers pretended to have shipped goods which, in fact, had not been delivered on board, and that the master and crew of a vessel taking in or discharging cargo out of four hatches are unable to control the proper delivery. Lastly, it must not be overlooked that, notwithstanding the clauses in the bills of lading, the shipowners often voluntarily agree to pay for damages or losses not covered by their guarantee, so that the necessity of reform does not appear to be so urgent as it is made by the shippers.

The so-called monopoly of the shipowners is next considered. The committee were of opinion that the alleged monopoly did not exist. The shippers can apply to other shipowners. They can, by their combined efforts, start steamship companies themselves. It is not true that the bills of lading are forced upon the merchants. They are known to the merchants and are frequently modified. It often happens that several steamship companies try to come into business with a shipper of goods, and the shipper avails himself of this competition in order to secure advantages for himself. The enormous abatement of freights also proves that there is no monopoly because, if the shipowners had a monopoly, they would have been able to keep up the high freights. It is notorious that competition has reduced the freights so much as, in many cases, scarcely to leave to the shipowner the means of paying his expenses.

Then, as to the encouragement of negligence and fraud, the report proceeds to say that this argument is not a sound one. Competition is a sufficient safeguard against these dangers. The owner who does not take care to prevent, as far as possible, the occurrence of losses and damages will soon lose his clients. The exonerating clauses do not make it to the interest of the shipowner to have the goods lost or damaged. Negligence in the control of their employees would make the shipowners liable, notwithstanding the clauses.

The committee, for these reasons, conclude that the principle of public order does not require the prohibition of exonerating clauses. The shipowner who confides his ship to the master risks the loss of his ship; similarly the shipper risks the loss of the goods confided to the master. The shipowner protects himself by insurance; similarly the shipper may protect himself by insurance. If he chooses not to do so, he is his own insurer. 
A law which prohibits the exonerating clauses could not prevent the consequence, viz.: the raising of freight rates in proportion to the greater risks incurred by the shipowner. This surplus of freight is equivalent to the insurance premium which the merchant has to pay if the risks are not covered by the shipowner. It follows that there is no sufficient reason for legislation instead of leaving the solution of the conflict between the owner and the merchant to the general law of economy. The legislator's duty is only to protect a person who invokes his protection against fraud and the clauses of irresponsibility cannot be considered to be a fraud to the prejudice of the merchant.

At any rate, all reasonable demands of the shippers are met by the offer of an alternative bill of lading. The surplus of freight stipulated by a French steamship company, the "Compagnie de Navigation Mixte," in I897, amounted to Ofr. 88c. à Ifr. 54c. per cent of the declared value, which seems to be but a moderate charge.

The report then proceeds to an examination of the Harter Act and the Australian Act relating to the sea carriage of goods of 15 th December, I904, which is, on the whole, a reproduction of the Harter Act with some slight alterations. The Harter Act, it is said, leaving alone the wording of the law, which might be amended, cannot be considered as an example which should be followed. The conclusion drawn from the fact that the Harter Act has not injured the development of the American trade or naval industry is not decisive because there are many concurring and always-changing reasons for this development between which it is hardly possible to distinguish, so as to ascertain whether any and what part is attributable to the law in question. It must be considered that the United States law, previous to the passing of the Harter Act, held the shipowner responsible not only for the so-called commercial but also for the nautical faults of the master and crew, and, therefore, in this respect, the Harter Act alleviated the responsibility of the shipowner. The clause by which the Harter Act prohibits certain exonerating clauses has in view, as is proved by the debates on the Bill, to protect the American exporters of grain and flour against foreign transporters so long as there is no American mercantile navy to carry out these transports. The national flag of the United States carries ten per cent only of their international sea transports. A committee of members of the Senate and the House of Representatives has been appointed to suggest remedies, and has arrived at the conclusion that subsidies were necessary to ameliorate the condition of the American shipowners. It is, therefore, not advisable to intro- 
duce the legislation of the United States into countries where the relations of commerce and navigation are entirely different from those in the United States.

Lastly, the question is considered from the point of view of the underwriters. And here the committee comes to the conclusion that, as far as the underwriters are concerned, the question simply comes to this: "Who is to pay the premium of the risks, the shipowner or the shipper?" And this, the committee says, is a question between private interests only, which does not justify the interference of legislation in a sense contrary to the principle of liberty of contracts.

V.

This report, of the main contents of which I have given a short abstract, presents to our eyes a vivid picture of the stage at which the movement which, for upwards of twenty years has engaged the attention of the commercial world, has at present arrived. It introduces the interested parties-the shippers, the shipowners, the underwriters. We hear their arguments. We learn what judgment, after the hearing. has been delivered by a body of eminent men directed to investigate this question by the government of a commonwealth which takes the highest rank amongst civilized nations. Thus we are enabled to form a judgment ourselves on a question which, for a long series of years, has occupied the attention' of this asociation also.

First of all, the question is formulated in a more precise form than has been done before. The question is whether legislation ought to interfere with the principle of liberty of contract by prohibiting certain clauses in bills of lading issued by steamship companies. There is no question about sailing-vessels; as to these no complaints are made. There is no question about charter-parties; as to these, also, no complaints are made. The clauses which are objected to by the shippers can be particularly specified. They are not the clauses which, since olden times, figure in the bills of lading, viz.: the clauses, "the act of God, enemies, pirates, and perils of the seas excepted," and the clauses, "weight and contents unknown." Nor are they the more recent clause, "not responsible for fire on board, collisions, strandings, explosions, or other accidents of navigation, even when occasioned by negligence, default, or error in judgment of the pilot, master, crew, or other servants of the shipowner, nor for clamage done on land, nor for obliteration, errors, insufficiency or absence of marks, numbers, address, or description," or similar clauses. 
The clauses objected to are those which exonerate the shipowner from liability for loss or damage on goods arising from negligence, fault, or failure of the master, officers, agents, or servants of the owner in proper loading, stowage, dunnage, care, and proper delivery of goods committed to their charge. In other words: "The shippers want the owner to be and remain responsible for all losses and damages on goods happening in the time between their delivery to the master, or officers, or servants of the owner, and the delivery to the consignee, except such as result from acts of God, or accidents of navigation, even if caused by the negligence of the master, officers and crews, or pilots, or other persons employed by the owner in the navigation of the vessel."

Thus the owner would be responsible for thefts, for want of due custody whilst the goods received are stored in sheds or lighters before being charged on board or delivered to the consignee, for bad stowage and dunnage, for want of proper care in ventilating during the voyage, for wrong delivery or non-delivery or late delivery at the port of destination, for the risks of transhipment, and for loading goods on deck without previous agreement with the shipper.

The question, therefore, is: Whether it is desirable to bring about a law which compels the shipowners to bear these responsibilities.

It seems to be clear that such a law, if given, could not be given by a single nation, but must be an international law. The shipowners, if prohibited from declining the responsibilities in question, must be allowed to raise their freights. This would prejudice the national merchant navy of the particular state. An agreement between the seafaring nations-at least, the principal amongst them-would, therefore, be indispensable.

This, however, is no reason for not trying to bring about an international law. The question, therefore, remains the same as stated above, only that the words, "an international law," must be substituted for the term, "a law," used above.

The only reason, in my opinion, why such a law could be deemed advisable, would be this-that the principle of public order required the law. This could be said only, if public interests suffered in the present state of things. This would be the case, if disorders of a public character-crimes or fraud-were the consequence of the present state of things, and could be prevented or diminished by passing such a law, or if the law were necessary or, at least, useful for preventing a loss of national wealth which arises from the present state of things. 
Both arguments, indeed, are brought forward by the partisans of the proposed reform. It is said that thefts and embezzlement of cargoes are encouraged by the masters and crews knowing that their owner cannot be held responsible, and therefore will not dismiss them on account of their misdemeanors. Professor Platou mentions the case of the steamship, "General Gordon," which arrived at St. Nazaire with a cargo of wheat, part of which was discharged, but the remainder clandestinely taken away to sea by the master. And it is said that the negligence of the owner's servants in handling the cargo is encouraged by the negligence clause, and thus values are lost which form a part of the national wealth. It is also said that the bills of lading are discredited by the negligence clause.

These arguments, in my opinion, are not of a nature to justify the proposed legislation. To support them, it must be proved that thefts and embezzlements have increased in number in consequence of the introduction of the negligence clause, and that, by prohibiting this clause, they will diminish. This, as yet, has not been proved. It also seems to be highly improbable that the crew of a steamship will be prevented from committing a theft by reflecting that, by committing such a crime, they will damage the owner. The master of the "General Gordon" would have sailed with the cargo just as well, if the negligence clause had not been inserted in the bill of lading. Nor can it be said that the negligence clause encourages masters and crews to commit thefts and embezzlements by leading them to think that the owner will not dismiss them because he suffers no damage. For every steamship company will most certainly dismiss such rogues, whether they be responsible for the damage done by them or not. And as to the credit of the bills of lading, it would have to be proved that the bankers who give their acceptance against bills of lading covered by insurance policies-and other bills of lading, as far as my knowledge goes, are not presented to bankers-distinguish between bills of lading without a negligence clause and bills of lading with a negligence clause. This proof, as yet, has not been given. Then there is the negligence in stowing the cargo, in providing proper dunnage, and caring for the cargo during the voyage, c. $g .$, by ventilation. It must be granted that the stowage, the dunnage, and the care for the cargo, will be better attended to, if the stevedores and the people on board know that the owners must pay for the want of such attention. But, in order to justify legislation to interfere, more than this is required. It must be shown that a waste of goods is, in fact, caused by bad stowage, or dunnage, and bad ventilation, and that the owners do not do their utmost to pre- 
vent such waste. The former fact has, as yet, not been proved, and, as to the latter, experience, as far as I know, shows that the big steamship companies all over the world do what is in their power to provide means for a careful handling of the cargo, as well as for good stowage and proper dunnage.

There is another question which must be considered with regard to the stowage, dunnage, and the handling of the cargo during the - voyage. Do not these duties of the master and officers belong to what is called navigation, and is not, therefore, a neglect of these duties an error or neglect of navigation, and, as such, part of the clauses which are admitted by the merchants? What is the difference between a master who endangers the cargo by neglecting carefully to supervise the stowage, or to care for a proper dunnage, and a master who endangers the cargo by not making a careful use of the log, or between an officer who omits to have a cargo of grain properly ventilated, and an officer who omits to have the hatches properly secured?

The same or similar reasons apply to the losses or damage on cargo which happen in sheds or lighters before coming on board or before being landed after their discharge. The modern mode of conducting the business of steamship lines is entirely different from what was done some thirty or forty years ago. The steamers are run in a certain line, goods are engaged for this line beforehand; the owners cannot guarantee the shipping of the goods at a certain time or with a certain vessel. The goods, therefore, must frequently be stored before shipment. The owners provide storage in public sheds or in sheds of their own. Likewise the cargo cannot be taken in or discharged in the same way as it was formerly. It must be brought alongside the vessel by lighters, or discharged into lighters. Or the prompt expedition of steamers, which benefits the whole commercial public, requires the landing of cargoes on quays before the consignees are ready to receive their goods. The goods are received by the steamship line before they come on board. Bills of lading are signed: "Received to be shipped on board." It is clear that, - thus, greater risks are run by the cargo during the time between the receipt by the vessel and the delivery to the consignee than at times when the bill of lading was only signed, "Received on board," and the cargo was taken from on board alongside the vessel. But, on the other hand, considerable advantages accrue to the merchants out of such a mode of conducting business. They save expenditure by having the goods stored in sheds of the steamship companies. They receive bills of lading sooner. They have not to provide the lighter- 
age for discharging the cargo. Under these circumstances, why should legislation prohibit the shipowner from saying: "Those extra risks must be borne by the merchant-they are not covered by the freight?" I cannot see that the principle of public interest is involved in this question.

The clause of transhipment, also, is justified by these reasons. And as to the non-delivery of goods at the port of destination and returning them by other vessels, it must be granted that this may happen by carelessness of the master or officers; but it may happen, also, through inadvertency of the shipper in properly marking the goods and the port of destination, and the short time of stay at intermediate ports in some degree excuses the mistakes. At any rate, no general public interest of importance is involved in this clause, as well as in the clause limiting the amount for which the owners are responsible in case of non-delivery or belated delivery, so as to justify the interference of legislation.

This, also, seems to be the case with deck loads. The merchants complain that goods are charged on deck without previous advertisement to the shipper. But, although it is true that bills of lading often contain the clause, "the vessel to be at liberty to stow goods on deck," still the merchant, who must know the form of the bills of lading, can easily avoid any risk by stipulating, on advising the shipment to the agent of the steamship company, that the goods are to be stowed below deck, or, if not, that he be informed in time to procure a proper insurance for them.

It needs no explanation that a clause which allows the owner to bring into general average damages done to the engines by the vessels going aground without an imminent peril is of no public interest whatever.

Lastly, it is said that legislation must forbid the owners to decline their liability for the neglect of all such duties as are performed by their paid employees. "Respondeat superior." But clearly this is no argument for the interference of legislation. Reasons of public policy only can justify this interference. It is said that the nature of the contract of affreightment involves the necessity of the said liability. But this is evidently erroneous because there is nothing to hinder making a contract which differs from the contracts of affreightment defined by law.

As to the alleged monopoly of steamship companies, it may be granted that merchants frequently are compelled to submit to the conditions of the bills of lading. But only, if they do not offer a higher freight. Before it can be said that the shipowners take 
undue advantage of their position, it must be proved that they refuse to increase their liability in consideration of a higher freight. This proof is, as yet, not given. The offer of an alternative bill of lading, made by the French steamship companies, is strong evidence to the contrary.

The result is that, for the present, at least, there is no reason for advocating legislative action in imitation of the Harter Act. Such legislation would be welcomed, certainly, by the underwriters on cargo. But it is evident that legislation cannot be invoked to improve the business of underwriters. If the risks are greater than formerly, the premiums must be raised. And the attitude of the underwriters at the above-mentioned Paris Conference-an attitude, which, naturally, will result in a raising of insurance premiums and not in making insurance impossible-seems to me to be fully justified if the present premiums are too low. But this is not a matter of public order, and, consequently, it affords no reason for interference by legislation.

VI.

If I am right thus far, the question for this association remains: Ought the Harter Act and bills of lading legislation to be dropped out of the programme of the International Law Association altogether?

I think not. It is true, as Sir Walter Phillimore remarked at the Christian Conference, that the general bill of lading proposed by the association at its London Conference in I893 has fallen stillborn. But this only proves that it is impossible to draft a bill of lading which suits all interests concerned, and is adapted to all the everchanging requirements of maritime commerce. It is not impossible, however, that abuses may arise which show the necessity of legislation. And it is possible, also, that iniquities may occur which could be successfully met by repeated discussions in meetings like those of this association. It is highly desirable that the commercial public shall know that the conferences of this association afford an opportunity of a public discussion on any well-founded complaints on the contents of bills of lading, and that it may be induced to communicate to this association any weil-founded complaints which they may have to make. Dr. F. Sieveking. 